\title{
Perlindungan Hukum Terhadap Kelangsungan Usaha Mikro, Kecil, dan Menengah Atas Pemberlakuan Masyarakat Ekonomi Asean
}

\author{
Ade Pratiwi Susanty* \\ Fakultas Hukum Universitas Lancang Kuning \\ Jalan Yos Sudarso Km 8, Rumbai, Kota Pekanbaru, Indonesia
}

\begin{abstract}
Abstrak
Tujuan penelitian ini untuk menjelaskan perlindungan hukum terhadap kelangsungan UMKM atas pemberlakuan MEA dan pengaruh pemberlakuan MEA terhadap UMKM di Indonesia. Metode penelitian yang digunakan dalam penelitian ini adalah penelitian hukum normatif dengan menggunakan pendekatan peraturan perundang-undangan. Berdasarkan hasil penelitian dapat dijelaskan perlindungan hukum terhadap kelangsungan UMKM atas pemberlakuan MEA diberikan dalam bentuk peraturan perundang-undangan. Terdapat tindakan-tindakan dalam upaya perlindungan hukum yang diperbolehkan diantaranya safeguard (pengamanan perdagangan), anti dumping dan standarisasi. Pengaruh positifnya UMKM di Indonesia memiliki kesempatan untuk mengembangkan usahanya di negara-negara ASEAN lainnya, sedangkan pengaruh negatifnya UMKM di Indonesia sebagian besar belum siap untuk bersaing dengan UMKM dari negara-negara ASEAN lainnya karena faktor permodalan, teknologi, dan pemasaran. Kesimpulan penelitian ini perlindungan hukum terhadap kelangsungan UMKM atas pemberlakuan MEA diberikan dalam bentuk peraturan perundang-undangan. Terdapat pengaruh positif dan negatif pemberlakuan MEA terhadap UMKM di Indonesia.
\end{abstract}

\section{Kata Kunci: UMKM, Perlindungan Hukum, MEA}

\begin{abstract}
The purpose of this study is to explain the legal protection of MSMEs' sustainability on the implementation of MEA and the effect of MEA implementation on MSMEs in Indonesia. The research method used in this research is normative law research using approach of legislation. Based on the results of the study can be explained legal protection of MSMEs on the implementation of the MEA given in the form of legislation. There are measures in legal safeguards that are allowed such as safeguards (trade safeguards), anti-dumping and standardization. The positive impact of MSMEs in Indonesia has the opportunity to expand its business in other ASEAN countries, while the negative impact of MSMEs in Indonesia is largely not ready to compete with MSMEs from other ASEAN countries due to capital, technology and marketing factors. The conclusion of this research is legal protection to MSMEs' sustainability on the implementation of MEA given in the form of legislation. There are positive and negative effects of MEA implementation on MSMEs in Indonesia.
\end{abstract}

Keywords: UMKM, Legal Protection, MEA

*Penulis Korespodensi

Email: ade_pratiwi.susanty@yahoo.co.id 


\section{Pendahuluan}

Perkembangan arus globalisasi membawa banyak perubahan dalam berbagai bidang kehidupan terutama dalam lalu lintas perdagangan internasional. Hal ini tentunya akan semakin menarik karena pasar global semakin kencang. Perdagangan internasional sendiri merupakan faktor yang sangat penting bagi setiap negara. Oleh karena itu, sangat diperlukan hubungan perdagangan antarnegara yang tertib dan adil. Untuk mewujudkan ketertiban dan keadilan di bidang perdagangan internasional, diperlukan aturan-aturan yang mampu menjaga serta memelihara hak-hak dan kewajiban para pelaku perdagangan internasional.

IImu pengetahuan dan teknologi sangat mempengaruhi kehidupan bangsa-bangsa di dunia. Sejalan dengan adanya perkembangan kehidupan bangsa-bangsa di dunia, semakin berkembang pula permasalahan-permasalahan dalam masyarakat internasional. Bentuk kehidupan yang kompleks sangat rentan untuk terjadinya perselisihan. Untuk menghindari agar tidak terjadi perselisihan maka masyarakat internasional harus senantiasa bertumpu pada norma atau aturan. Aturan tersebut tidak hanya dibuat untuk menghindari perselisihan, tetapi juga untuk menertibkan, mengatur, dan memelihara hubungan antarnegara. ${ }^{1}$

Masyarakat internasional pada hakikatnya diartikan sebagai suatu kompleks kehidupan bersama yang terdiri dari aneka ragam masyarakat yang jalin-menjalin dengan erat. ${ }^{2}$ Kehidupan masyarakat internasional yang terjalin merupakan hubungan resmi antara negara-negara. Negara memiliki posisi utama dalam menjalin hubungan di dalam masyarakat internasional. Hal ini dikarenakan negara secara politis maupun yuridis mempunyai kekuasaan teritorial yang bersifat mutlak. Dalam perkembangan kehidupan bersama manusia yang cenderung semakin tidak mengenal batas negara ini, dapat dimungkinkan terjadi kesepakatan antar negara-negara dalam menyelesaikan berbagai persoalan.

Perangkat hukum internasional yang mengatur hubungan dagang antarnegara terkandung dalam dokumen GATT (General Agreement on Tariff and Trade) yang ditandatangani oleh negara-negara pada tahun 1947, dan mulai diberlakukan tahun 1948. Dari waktu ke waktu, ketentuan GATT disempurnakan lewat berbagai perundingan, terakhir lewat perundingan Putaran Uruguay yang berhasil membentuk sebuah organisasi perdagangan dunia bernama World Trade Organization (WTO). ${ }^{3}$ Badan inilah yang selanjutnya akan melaksanakan dan mengawasi aturan-aturan perdagangan internasional yang telah dirintis oleh GATT sejak tahun 1947. Perdagangan yang melewati batas-batas wilayah suatu negara mempunyai peranan yang penting apabila ekonomi dunia diharapkan kembali ke jalur pertumbuhan yang lebih cepat. Salah satu bidang yang saat ini cukup berkembang adalah perdagangan bebas (free trade), termasuk perdagangan bebas antara negara-negara di dunia ini, di mana prinsip perdagangan bebas diakui sebagai suatu solusi terbaik dan adil bagi berjalannya roda perekonomian dunia. ${ }^{4}$

${ }^{1}$ Mohd. Burhan Tsani, Hukum dan Hubungan Internasional, (Yogyakarta: Liberty, 1990), hlm. 7.

${ }^{2}$ Mochtar Kusumaatmadja dan Etty R. Agoes, Pengantar Hukum Internasional, (Bandung: Alumni, 2003), hlm. 13.

${ }^{3}$ Syahmin AK, Hukum Dagang Internasional Dalam Kerangka Studi Analitis, (Jakarta: Raja Grafindo Persada, 2006), hlm. 12. 
ASEAN Free Trade Area (AFTA) adalah bentuk dari kerjasama perdagangan dan ekonomi di wilayah ASEAN yang berupa kesepakatan untuk menciptakan situasi perdagangan yang seimbang dan adil melalui penurunan tarif barang perdagangan, tidak ada hambatan tarif (bea masuk $0-5 \%$ ) maupun hambatan nontarif bagi negara-negara anggota ASEAN. AFTA disepakati pada tanggal 28 Januari 1992 di Singapura. Pada awalnya, ada enam negara yang menyepakati AFTA, yaitu Brunei Darussalam, Indonesia, Malaysia, Filipina, Singapura, dan Thailand. Vietnam bergabung dalam AFTA pada tahun 1995, sedangkan Laos dan Myanmar pada tahun 1997, kemudian Kamboja pada tahun 1999. Adapun tujuan AFTA untuk meningkatkan daya saing ekonomi negara-negara ASEAN dengan menjadikan ASEAN sebagai basis produksi pasar dunia untuk menarik investasi dan meningkatkan perdagangan antaranggota ASEAN. Mekanisme utama mencapai tujuan di atas dengan skema Common Effective Preferential Tariff (CEPT) yang bertujuan agar barang-barang yang diproduksi di negara ASEAN memenuhi ketentuan setidak-tidaknya $40 \%$ kandungan lokal akan dikenai tarif hanya $0-5 \%{ }^{5}$

Konsep Masyarakat Ekonomi ASEAN sejalan dengan dinamika hubungan antarbangsa di ASEAN yang menyadari pentingnya integrasi negara-negara di Asia Tenggara. Pada pertemuan informal para Kepala Negara ASEAN di Kuala Lumpur tanggal 15 Desember 1997 disepakati ASEAN Vision 2020 yang kemudian ditindaklanjuti dengan pertemuan di Hanoi yang menghasilkan Hanoi Plan of Action (HPA). Visi 2020 termasuk HPA berisi kondisi yang ingin diwujudkan dibeberapa bidang, seperti orientasi ke luar, hidup berdampingan secara damai, dan menciptakan perdamaian internasional. ${ }^{6}$

Indonesia bersama dengan sembilan negara ASEAN lainnya pada 31 Desember 2015 telah menyepakati berlakunya Masyarakat Ekonomi ASEAN (MEA) atau ASEAN Economic Community (AEC). MEA merupakan realisasi pasar bebas di Asia Tenggara yang sebelumnya telah disebut dalam AFTA pada tahun 1992. MEA akan menjadikan kawasan Asia Tenggara ini, seperti sebuah negara besar. Penduduk di kawasan ASEAN akan mempunyai kebebasan untuk melakukan perdagangan, masuk ke satu negara dan keluar dari negara lain di kawasan ASEAN tanpa membutuhkan paspor. Mereka mempunyai kebebasan dan kemudahan untuk memilih lokasi pekerjaan yang dianggap memberi keuntungan dan kepuasan. Perusahaan juga bebas memilih lokasi pabrik dan kantor perusahaan di kawasan negaranegara ASEAN.

Tingkat daya saing yang belum memuaskan dan iklim investasi yang belum sepenuhnya mendukung kalangan dunia usaha harus menjadi prioritas masalah yang harus diselesaikan. Kesiapan para pelaku usaha di bidang Usaha Mikro, Kecil, dan Menengah (UMKM) perlu menjadi perhatian serius pemerintah menghadapi persaingan yang ketat

${ }^{4}$ http://www.finance.detik.com/read/2010/03/14/190620/1318025/4/penerapan-acfta-untungkanindonesia, diakses 30 Oktoberi 2017. hlm. 246.

${ }^{5}$ Hendera Halwani, Ekonomi Internasional dan Globalisasi Ekonomi, (Jakarta: Ghalia Indonesia,2002),

${ }^{6}$ Atep Abdurofiq, Menakar Pengaruh Masyarakat Ekonomi Asean 2015 Terhadap pembangunan Indonesia, Jurnal Sosial dan Budaya Syar'i, Volume 1, Nomor 2, Tahun 2014, hlm. 251. 
dengan pelaku UMKM di negara-negara ASEAN lainnya. Banyak para pelaku UMKM di daerahdaerah yang belum memahami MEA.

Pelaksanaan MEA akan mengakibatkan tingginya tingkat persaingan sehingga hanya perusahaan besar yang mampu akan terus berkembang. Perusahaan besar tersebut diperkirakan terus menekan industri kecil yang pada umumnya kurang mampu bersaing dengan para konglomerat. Meskipun UMKM telah menunjukkan peranannya dalam perekonomian nasional, namun masih menghadapi berbagai hambatan dan kendala, baik yang bersifat internal maupun eksternal, dalam hal produksi dan pengolahan, pemasaran, sumber daya manusia, desain dan teknologi, permodalan, serta iklim usaha. Untuk meningkatkan kesempatan, kemampuan, dan perlindungan UMKM, telah ditetapkan berbagai kebijakan tentang pencadangan usaha, pendanaan, dan pengembangannya, namun belum optimal. Hal itu dikarenakan kebijakan tersebut belum dapat memberikan perlindungan, kepastian berusaha, dan fasilitas yang memadai untuk pemberdayaan UMKM. Selain itu, sangat diperlukan perlindungan hukum yang diberikan pemerintah kepada UMKM atas pemberlakuan MEA.

Paling penting adalah menekan harga produk lokal sehingga dapat bersaing dengan produk-produk impor. Inilah mengapa perlunya menciptakan biaya produksi rendah. Biaya produksi rendah bagi industri dalam negeri dapat diciptakan pertama dengan menurunkan suku bunga pinjaman bank. Suku bunga pinjaman yang diterapkan di Indonesia sebesar $13,6 \%$. Suku bunga tersebut dianggap terlalu tinggi dan membebani para pengusaha, terutama pengusaha UMKM. Bunga yang relatif tinggi memberikan keengganan bagi perusahaan maupun perorangan untuk meminjam uang karena biayanya dianggap masih mahal. $^{7}$

Implikasi bunga pinjaman yang tinggi lainnya akan menyebabkan sektor manufaktur sulit bersaing. Bunga pinjaman tersebut akan membebani ongkos kapital sehingga menaikkan biaya produksi. Selanjutnya, seperti yang telah disebutkan di atas, yakni membuat biaya produksi tinggi dan memaksa harga produkpun menjadi lebih mahal. Dengan demikian, diperlukan penurunan suku bunga pinjaman agar meringankan beban biaya produksi dan juga mendorong pembukaan usaha-usaha baru agar terbuka kesempatan kerja yang lebih luas. ${ }^{8}$

Kemudian memperbaiki infrastruktur. Infrastruktur memang tak dipungkiri merupakan variabel yang sangat krusial dalam memacu roda perekonomian. Bahkan, secara ekonomi makro, ketersediaan dari jasa pelayanan infrastruktur mempengaruhi marginal productivity of private capital, sedangkan dalam konteks ekonomi mikro, ketersediaan jasa pelayanan infrastruktur berpengaruh terhadap pengurangan biaya produksi. Penurunan kinerja infrastruktur berimplikasi pada terhambatnya distribusi barang dan jasa yang menyebabkan kenaikan biaya angkut sehingga biaya produksi meningkat. Hal inilah yang menjadi alasan bahwa perbaikan infrastruktur akan sangat menekan biaya produksi. ${ }^{9}$

UMKM memang menunjukkan ketidaksiapan disebabkan oleh daya saing usaha masyarakat yang lemah dan tidak mampu

${ }^{7}$ http://www.rosalinadia.blogspot.com/2011/01/dilema-pemberlakuan-acfta-asean-china.html, diakses 30 Oktober 2017.

${ }^{8} / \mathrm{bid}$.

${ }^{9} /$ bid. 
bersaing. Sejak Orde Baru hingga Era Reformasi, sudah banyak upaya pemerintah membantu perkembangan UMKM dalam bentuk beragam program, mulai dari pemberian kredit murah hingga bantuan teknis. Namun, UMKM di Indonesia masih jauh tertinggal. Kemungkinan pendekatan strategi pemberdayaan UMKM yang kurang tepat antara lain:

1. Pemerintah lebih fokus pada pemberian kredit, bukan bantuan teknis/ teknologi di bidang utama yang sangat menentukan daya saing, yakni produksi, manajemen, dan pemasaran. Pemberian dana/kreditpun lebih banyak dimanfaatkan untuk kebutuhan konsumtif, bukan untuk investasi atau untuk mendanai kegiatan research and development dan inovasi.

2. UMKM masih dipandang sebagai alat untuk mengurangi kemiskinan dari pada bagian untuk meningkatkan kapasitas dan daya saing industri nasional.

3. Pemerintah belum serius mengembangkan industri pendukung yang membuat barang-barang modal dan pembantu serta komponen dengan UMKM sebagai pemain utama.

Dengan adanya pemberlakuan MEA, perlu perubahan strategi kebijakan untuk meningkatkan daya saing UMKM, yaitu bantuan yang diberikan pemerintah harus sepenuhnya tertuju pada upaya peningkatan kemampuan teknologi, pengetahuan dalam produksi, manajemen, dan pemasaran. Fokus bantuan harus pada penguatan capacity building dengan inovasi dan kreatifitas (dalam produksi, manajemen, dan pemasaran) sebagai motor penggerak utama.

Dalam penelusuran penulis ada beberapa penelitian sebelumnya terkait UMKM berdasarkan Undang-Undang Nomor 20 Tahun 2008 tentang Usaha Mikro, Kecil, dan Menengah dan Pasar Bebas secara umum, tetapi tidak menyinggung tentang Peraturan Menteri Perindustrian Nomor 37/M-IND/PER/6/ 2006 tentang Pengembangan Jasa Konsultasi bagi Industri Kecil dan Menengah dan Peraturan Menteri Perdagangan Nomor 14/M-DAG/PER/ 3/2007 tentang Standarisasi dan MEA. Rina Novia Putri dalam penelitiannya berjudul Kebijakan Indonesia dalam mengatasi dampak negatif China-Asean Free Trade Area (CAFTA) menjelaskan bagaimana pemerintah meminimalisir dampak negatif dari pelaksanaan CAFTA, yaitu dengan mengeluarkan 3 (tiga) kebijakan berupa deregulasi tarif dan kuota impor, penguatan ekonomi berbasis UMKM, dan pembangunan infrastruktur. Ketiga kebijakan ini diharapkan mengurangi dampak negatif dari pelaksanaan CAFTA yang terjadi di Indonesia, salah satunya menekan angka impor dari China dan meningkatkan angka ekspor Indonesia ke negara lain. ${ }^{10}$

Teguh Sulistia dalam penelitiannya yang berjudul "Perlindungan Hukum dan Pemberdayaan Pengusaha Kecil dalam Ekonomi Pasar Bebas", menjelaskan bahwa pemberdayaan usaha kecil sebagai penguatan ekonomi rakyat dapat dilakukan melalui peningkatan aspek pemodalan, kebebasan pasar dan penguasaan teknologi. Kebijakan ekonomi ini hendaknya berpihak pada ekonomi rakyat demi dapat mengejar ketinggalan dalam persaingan usaha

${ }^{10}$ Rina Novia Putri, Kebijakan Indonesia Dalam Mengatasi Dampak Negatif China-Asean Free Trade Area (CAFTA), Skripsi Program Studi IImu Hubungan Internasional Fakultas IImu Sosial dan Politik Universitas Jember, Tahun 2016, hlm. 69. 
dan pasar bebas. Pemberdayaan yang dilakukan terhadap UMKM tidak dapat lepas dari perlindungan hukum, sebab penerapan pasar bebas tentunya akan menimbulkan persaingan usaha yang tidak sehat. ${ }^{11}$

Minasri dalam penelitiannya yang berjudul "Peran Pemerintah Dalam Pasar Bebas" menjelaskan bahwa dalam hal perlindungan hukum terhadap usaha kecil dalam menghadapi era pasar bebas pemerintah khususnya Kota Yogyakarta dalam hal ini membentuk sebuah organisasi yang bernama Griya UMKM sebagai realisasi amanat dari Undang-Undang Nomor 20 Tahun 2008 tentang Usaha Mikro, Kecil, dan Menengah. Pembentukan organisasi ini tidak lain demi mempertahankan eksistensi usaha kecil agar dapat bersaing di era pasar bebas. ${ }^{12}$ Dalam penelitian ini Minasri membatasi penelitiannya pada Kota Yogyakarta. Hal ini berbeda dengan penelitian penulis yang lebih bersifat umum.

Memperhatikan hasil penelitian terdahulu tersebut jelaslah tidak berkaitan dengan perlindungan hukum terhadap kelangsungan UMKM atas pemberlakuan MEA, sehingga penelitian yang penulis lakukan merupakan suatu kebaruan (novelty). Oleh karena itu, penelitian ini menjadi penting dilakukan karena akan memberikan konstribusi dalam pengetahuan. Adapun permasalahan yang akan dibahas dalam penelitian ini: Pertama, bagaimanakah perlindungan hukum terhadap kelangsungan UMKM atas pemberlakuan MEA? Kedua, bagaimanakah pengaruh pemberlakuan MEA terhadap UMKM di Indonesia?

Untuk menjawab pertanyaan tersebut penulis mengunakan pendekatan hukum normatif. Tujuan yang diharapkan dari penelitian ini untuk menjelaskan perlindungan hukum terhadap kelangsungan UMKM atas pemberlakuan MEA dan pengaruh pemberlakuan MEA terhadap UMKM di Indonesia.

\section{Metode Penelitian}

Metode penelitian yang digunakan dalam penelitian ini adalah penelitian hukum normatif dengan menggunakan pendekatan peraturan perundang-undangan. Penelitian hukum normatif dilakukan dengan cara meneliti bahan pustaka. Dalam penelitian hukum normatif, bahan pustaka merupakan data dasar yang dalam ilmu penelitian digolongkan sebagai data sekunder. ${ }^{13}$ Sumber data yang digunakan dalam penelitian ini berupa bahan hukum primer dan bahan hukum sekunder. Data yang terkumpul selanjutnya dianalisis secara kualitatif dan pada akhirnya disimpulkan dengan metode deduktif.

\section{Pembahasan}

\section{Perlindungan Hukum Terhadap Kelang- sungan UMKM atas Pemberlakuan MEA}

Pengaturan perdagangan regional, sekelompok negara sepakat untuk menghilangkan atau mengurangi rintangan-rintangan terhadap impor dari sesama anggotanya telah berlangsung dibeberapa region dunia, seperti

\footnotetext{
${ }^{11}$ Teguh Sulistia, Perlindungan Hukum dan Pemberdayan Pengusaha Kecil Dalam Ekonomi Pasar Bebas, Jurnal Hukum Bisnis, Volume 27, Nomor 1, Tahun 2008, hlm. 22.

${ }^{12}$ Minasri, Perlindungan Hukum Terhadap Usaha Kecil Dalam Menghadapi Era Pasar Bebas Ditinjau Dari Undang- Undang No. 20 tahun 2008 tentang Usaha Mikro, Kecil dan Menengah, Skripsi, Program Studi IImu Hukum Fakultas Syari'ah dan Hukum Universitas Islam Negeri Sunan Kalijaga, Tahun 2014, hlm. xii.

${ }^{13}$ Soejono Soekanto dan Sri Mamudji, Penelitian Hukum Normatif; Suatu Tinjauan Singkat, (Jakarta: Raja Grafindo Persada, 2009), hIm. 234-242.
} 
Europan Union dengan pasar tunggalnya dan ASEAN dengan AFTA-nya. GATT mengakui adanya integrasi yang erat dalam bidang ekonomi melalui perdagangan yang lebih bebas.

Kerja sama perdagangan regional dapat diartikan menjadi dua konsep utama, yakni regional cooperation (kerja sama regional) dan regional integration (penyatuan regional). Pada dasarnya, alasan suatu negara melakukan perdagangan internasional dengan negara lain adalah sama, yaitu untuk memperoleh keuntungan dari pertukaran barang dan jasa yang dihasilkan dari spesialisasi pada bidang yang memiliki keunggulan komparatif pada masing-masing negara. Spesialisasi yang dilakukan dapat meningkatkan standar kehidupan. ${ }^{14}$

Perdagangan internasional adalah kegiatan yang berkaitan dengan adanya hubungan-hubungan komersial yang sifatnya hukum perdata dan transaksi-transaksi kegiatan tersebut dilakukan dalam konteks berbeda negara atau lintas negara. ${ }^{15}$ Perdagangan internasional timbul terutama sekali karena suatu negara bisa menghasilkan barang tertentu secara lebih efisien daripada negara lain. Alasan pokok mengapa perdagangan internasional tumbuh dengan cepat, yaitu Pertama, liberalisasi perdagangan dan investasi membuat penurunan tarif, kuota, pengendalian mata uang, dan hambatan terhadap arus barang dan modal internasional lainnya. Walaupun besarnya liberalisasi tiap negara berbeda-beda,. Kedua, penyempitan ruang ekonomi yang belum pernah dibayangkan sebelumnya telah terjadi melalui perbaikan pada teknologi komunikasi dan transportasi yang sangat pesat dan berakibat pengurangan biaya.

Pesatnya pembangunan diberbagai sektor menunjukkan iklim investasi yang kondusif bagi investor, oleh karenanya pemerintah berkewajiban memberikan pengarahan dan bimbingan terhadap pelaku usaha serta menciptakan iklim yang sehat bagi perkembangan usaha, sebaliknya dunia usaha juga perlu memberikan tanggapan terhadap pengarahan dan bimbingan serta penciptaan iklim tersebut dengan kegiatan-kegiatan yang nyata. Dalam rangka pencapaian pertumbuhan industri dan perdagangan aspek perizinan, bimbingan teknis bagi UMKM serta perlindungan konsumen ikut memainkan peranan yang penting.

UMKM memiliki peranan yang cukup kuat dalam pembangunan ekonomi di Indonesia, karena sebagian besar jumlah penduduknya berpendidikan rendah dan hidup dalam kegiatan usaha kecil baik dalam sektor tradisional maupun modern. Peranan UMKM ini menjadi bagian yang diutamakan dalam setiap perancanaan tahapan pembangunan. Namun, jika dilihat hasilnya maka belum cukup memuaskan karena pada kenyataannya kemajuan UMKM sangat kecil dibandingkan dengan usaha besar. Hal tersebut dilihat dari lebih berkembangnya pengusaha-pengusaha besar yang mencakup semua sektor, baik dari sektor perdagangan, perbankan, kehutanan, pertanian, dan terutama industri. ${ }^{16}$

${ }^{14}$ Rifai Afin, Herry Yulistio, dan Nur Alfillai Oktariani, Perdagangan Internasional, Investasi Asing, dan Efisiensi Perekonomian Negara-negara ASEAN, Jurnal Ekonomi dan Bisnis, Volume 8, Nomor 5, Tahun 2008, hlm. 262.

${ }^{15}$ Boediono, Ekonomi Internasional, (Yogyakarta: BPFE, 1981), hlm.19.

${ }^{16}$ Tiktik Sartika Partomo dan Abd.Rachman Soejoedono dalam Yunita R. Panjaitan, Perlindungan Hukum Terhadap Usaha Mikro Kecil dan Menengah Dalam Pasar Bebas Asean-China Free Trade Area, Jurnal Hukum Ekonomi, Volume 1, Nomor 2, Tahun 2013, hlm. 3. 
Orientasi pemberdayaan UMKM mencakup dua fokus, yaitu pemberdayaan UMKM. Pemberdayaan usaha mikro pada dasarnya diarahkan untuk mendukung penanggulangan kemiskinan dan peningkatan pendapatan masyarakat berpendapatan rendah, sedangkan, pemberdayaan usaha kecil dan menengah diarahkan untuk menurunkan angka pengangguran dan mendorong ekspor bersamaan dengan upaya mendorong perekonomian daerah. Pemberdayaan UMKM perlu dilaksanakan melalui langkah-langkah yang terencana, sistematis, institusional dan konsisten dengan didukung partisipasi masyarakat yang luas. Langkah pemberdayaan yang penting membuka kesempatan berusaha dan meningkatkan kualitas sumberdaya manusia UMKM, terutama pada jiwa kewirausahaannya. Perluasan kesempatan berusaha bagi UMKM diwujudkan dengan menciptakan iklim usaha yang kondusif melalui upaya bersama pemerintah pusat dan daerah untuk: ${ }^{17}$

1. Menyederhanakan proses perizinan usaha serta menyediakan adanya kepastian lokasi usaha.

2. Mengurangi biaya transaksi, terutama menghapus biaya-biaya pungutan praktik usaha yang curang.

3. Memantau dan memperbaiki regulasi dan kebijakan, baik sektoral maupun daerah, yang menghambat perkembangan UMKM.

Peningkatan akses terhadap sumber daya produktif meliputi akses kepada sumbersumber permodalan/pembiayaan, teknologi, pasar, dan informasi. Pengembangan institusi/ lembaga yang dapat menjalankan fungsi intermediasi berbagai sumber daya produktif tersebut di seluruh daerah menjadi program penting agar UMKM dapat memanfaatkan peluang yang tersedia. Selain itu, pelatihan dan pendampingan yang berkesinambungan bagi peningkatan kualitas sumber daya manusia UMKM menjadi satu kesatuan dari upaya pemberdayaan tersebut. Berkaitan dengan kebijakan pemberdayaan UMKM, diarahkan untuk menyederhanakan perizinan, mendorong pengembangan jasa konsultasi bagi industri kecil dan menengah, meningkatkan akses permodalan, dan memperkuat kemitraan usaha besar dan UMKM. Untuk mendorong pengembangan jasa konsultasi bagi industri kecil dan menengah, telah diterbitkan Peraturan Menteri Perindustrian Nomor 37/M-IND/PER/6/ 2006 tertanggal 27 Juni 2006 tentang Pengembangan Jasa Konsultasi bagi Industri Kecil dan Menengah. Dalam upaya peningkatan akses permodalan bagi UMKM, pemerintah telah menyiapkan rancangan skema kredit investasi bagi UMKM dan insentif fiskal bagi UMKM yang memanfaatkan teknologi inovatif. ${ }^{18}$

UMKM hanya mengandalkan modal sendiri untuk mengembangkan usahanya. Padahal upaya pemerintah dalam pemberian modal sangat membantu para pelaku usaha industri dalam menjalankan usahanya dan meningkatkan jumlah produksi. Pada hakikatnya, berbagai kebijakan dan perlindungan hukum memang harus dibuat agar para pelaku UMKM dapat bersaing secara nasional dan internasional.

Tataran pemberdayaan UMKM terdiri atas tataran makro, tataran meso, dan tataran mikro. Tataran makro merupakan kebijakan perbaikan

\footnotetext{
${ }^{17}$ Kementerian Negara Perencanaan Pembangunan Nasional, Pengembangan Ekonomi Daerah dan Sinergi Kebijakan Investasi Pusat-Daerah, (Jakarta: BAPPENAS, 2007), hlm. 30.

${ }^{18}$ Ibid.
} 
lingkungan usaha yang diperlukan untuk mendukung perkembangan UMKM. Beberapa isu lingkungan usaha diantaranya, yaitu terkait regulasi, persaingan usaha, biaya transaksi, peran pemerintah, swasta, dan masyarakat. Tataran meso merupakan peningkatan akses UMKM kepada sumber daya produktif dalam rangka meningkatkan kesehatan dan perluasan usaha. Pada tataran ini, fokus pada pengembangan kelembagaan dan peningkatan kapasitas untuk mendukung perkembangan jaringan usaha dan pemasaran, peningkatan akses UMKM kepada sumber permodalan, serta peningkatan intensitas penerapan teknologi yang sesuai dengan kebutuhan UMKM. Tataran mikro mencakup persoalan yang paling mendasar dalam pemberdayaan UMKM, yaitu pada karakteristik perilaku dan kapasitas pelaku usaha. Pada tataran ini, fokus pada upayaupaya penumbuhan kewirausahaan dan budaya kerja serta pengembangan sumber daya pelaku usaha yang berdaya saing.

Dalam rangka untuk mencapai hasil yang optimal, pemerintah menetapkan strategi pemberdayaan UMKM dalam bentuk:

1. Strategi peningkatan iklim usaha yang kondusif bagi UMKM

Aspek penting dalam peningkatan iklim usaha adalah pengembangan perundang-undangan dan kebijakan yang memudahkan serta berpihak pada tumbuh dan berkembangnya kelembagaan dan usaha UMKM secara nasional. Termasuk dalam hal ini penataan peraturan perundangundangan di bidang UMKM dan sinkronisasi peraturan perundangundangan di tingkat nasional dan daerah. Di sisi lain, perlu melakukan pengembangan berbagai kebijakan bidang Lembaga Keuangan Mikro
(LKM), pembentukan forum dan peningkatan koordinasi, peningkatan kemampuan dan kualitas aparat pembina khususnya di daerah, pengembangan dan peningkatan kualitas informasi UMKM, termasuk pengembangan sistem dan jaringan informasi.

2. Strategi pengembangan produk dan pemasaran bagi UMKM

Peningkatan produk UMKM yang berkualitas, inovatif, dan kreatif merupakan mata rantai yang perlu mendapat perhatian dalam pengembangan pemasaran dan jaringan usaha UMKM. Koordinasi antara produksi dan pemasaran mutlak dilakukan untuk mengarahkan pada upaya pemberdayaan UMKM yang terpadu dan berkesinambungan. Aspek penting dalam produksi adalah peningkatan produktifitas UMKM dan sekaligus peningkatan nilai tambah dengan pemanfaatan teknologi yang dipadu oleh perkembangan ilmu pengetahuan yang kaya akan inovasi produk. Adapun aspek penting dalam pemasaran dan penguatan jaringan usaha ditujukan pada penguasaan pasar dalam negeri dan peningkatan pasar ekspor. Secara khusus, pemerintah telah menugaskan Lembaga Layanan Pemasaran Usaha Kecil dan Menengah sebagai unit bisnis yang mandiri, tetapi tetap merupakan unit kerja di bawah kementerian untuk memberikan fasilitas promosi produk UMKM di pasar domestik maupun internasional. Lingkup kegiatannya promosi produk unggulan, menyediakan informasi pasar, dan menyediakan sumber daya manusia serta 
mengembangkan kemitraan UMKM untuk menjalankan fungsi pemasaran dan pelatihan pemasaran produk UMKM.

3. Strategi peningkatan daya saing sumber daya manusia UMKM

Pengembangan sumber daya manusia merupakan bagian dari upaya penumbuhan kualitas dan jumlah wirausaha. Dalam hal ini, aspek penting dalam pengembangan sumber daya manusia berkaitan dengan kewirausahaan, manajerial, keahlian teknis, dan keterampilan dasar.

4. Strategi penguatan kelembagaan UMKM

Upaya penguatan kelembagaan UMKM, selain ditujukan pada peningkatan kualitas kelembagaan, juga dilakukan untuk meningkatkan jumlah pelaku usaha.

5. Strategi peningkatan akses kepada sumber daya produktif

Peningkatan akses kepada sumber daya produktif diantaranya berkaitan secara langsung dengan pembiayaan yang sesuai dengan kebutuhan dan pengembangan usaha UMKM. Oleh karena itu, strategi pengembangannya ditujukan pada penguatan permodalan bagi UMKM dalam berbagai bentuk skim kredit, khususnya Kredit Usaha Rakyat (KUR), dan berbagai bentuk skim lainnya yang lebih murah dan mudah. Untuk memberikan cakupan yang lebih luas, selain dukungan dan pembiayaan langsung kepada pelaku usaha, pengembangan ditujukan pada Lembaga Keuangan Mikro, yaitu Koperasi Simpan Pinjam (KSP). Dalam hal ini perlu diupayakan solusi penurunan suku bunga pinjaman dan berbagai kemudahan lain, khususnya bagi kredit mikro dan kecil. Selain itu, dalam rangka memberikan layanan pembiayaan secara spesifik kepada UMKM, pemerintah telah menugaskan Lembaga Pengelola Dana Bergulir (LPDB) yang secara khusus memberikan pinjaman dan bentuk pembiayaan lainnya yang sesuai dengan kebutuhan UMKM. Lingkup pembiayaan dilakukan dalam bentuk pinjaman kepada UMKM strategis melalui lembaga perantara, pembiayaan kepada UMKM melalui perusahaan modal ventura. Strategi yang dapat dilakukan oleh pelaku UMKM, yaitu agar dapat meningkatkan kreatifitas, pandai melihat selera konsumen, membuat kemasan lebih menarik, dan mengikuti pameran-pameran sebagai ajang promosi produk. Selain itu, para pelaku UMKM agar dapat bersaing haruslah mempunyai inovasi dalam hal menghasilkan suatu produk agar dapat menarik konsumen untuk membelinya.

Berkaitan dengan perlindungan hukum terhadap pelaku UMKM atas pemberlakuan MEA, yaitu adanya undang-undang kemitraan yang mana bentuk kemitraan yang dilakukan oleh pelaku usaha yang satu dengan yang lainnya sehingga terjadi kerja sama dalam hal meningkatkan produksi usahanya, adanya standarisasi terhadap produk-produk dalam negeri yang dihasilkan yang disebut dengan Standarisasi Nasional Indonesia (SNI), serta adanya pemberian pelatihan-pelatihan dan bantuan modal kerja kepada para pelaku usaha. Selain itu, memberikan perlindungan kepada pelaku usaha, seperti adanya bea masuk yang 
dikenakan terhadap barang-barang yang masuk ke Indonesia. Berdasarkan ketentuan WTO mengenai adanya prinsip-prinsip hukum perdagangan internasional yang salah satunya menyebutkan adanya prinsip tarif mengikat (binding tariff principle). Prinsip ini diatur dalam Article II Section (2) GATT-WTO 1995, bahwa setiap negara anggota WTO harus mematuhi berapapun besarnya tarif yang telah disepakatinya, atau disebut dengan prinsip tarif mengikat.

Perlindungan hukum kepada pelaku UMKM sebagaimana penjelasan sebelumnya dapat juga dilihat dalam bentuk peraturan perundang-undangan, seperti Undang-Undang Nomor 20 Tahun 2008 tentang Usaha Mikro, Kecil, dan Menengah (selanjutnya disebut UU tentang Usaha Mikro, Kecil, dan Menengah), Peraturan Menteri Perindustrian Nomor 37/MIND/PER/6/2006 tentang Pengembangan Jasa Konsultasi bagi Industri Kecil dan Menengah, dan Peraturan Menteri Perdagangan Nomor 14/ M-DAG/PER/3/2007 tentang Standarisasi.

Apabila dikaitkan antara pemberdayaan yang diberikan oleh pemerintah kepada pelaku UMKM maka terdapat tindakan-tindakan dalam upaya perlindungan hukum yang diperbolehkan bagi industri dalam negeri tersebut, diantaranya: ${ }^{19}$

1. Safeguard (pengamanan perdagangan) Safeguard merupakan bentuk perlindungan terhadap industri dalam negeri yang mengalami kerugian atau ancaman kerugian yang disebabkan oleh meningkatnya impor dengan membatasi barang-barang impor yang impornya mengalami peningkatan. Tindakan safeguard dimaksudkan untuk menghindari keadaan, di mana anggota WTO menghadapi suatu dilema antara membiarkan pasar dalam negeri mereka yang sangat terganggu oleh barang impor atau menarik diri dari kesepakatan. Ketentuan mengenai pengaturan safeguard di Indonesia ada dalam Keputusan Presiden Nomor 84 Tahun 2002 tentang Tindakan Pengamanan Industri Dalam Negeri dari Akibat Lonjakan Impor. Tindakan penyelamatan safeguard dilakukan lebih ke arah penyelidikan pada peningkatan impor secara umum yang terjadi dalam periode dan keadaan tertentu. Peningkatan impor yang dimaksud terjadi dalam praktik perdagangan yang fair atau dalam persaingan yang normal. Apabila terbukti kuat bahwa terjadinya lonjakan impor dari barang terselidik telah mengakibatkan kerugian serius atau ancaman kerugian serius bagi industri dalam negeri maka tindakan pengamanan sementara dapat dikenakan.

\section{Anti dumping}

Dumping adalah praktik dagang yang dilakukan eksportir dengan menjual komoditi di pasaran internasional dengan harga yang kurang dari nilai yang wajar atau lebih rendah dari harga barang tersebut di negerinya sendiri atau dari harga jual kepada negara lain pada umumnya. Praktik dumping ini dinilai tidak adil karena dapat merusak pasaran dan merugikan produsen pesaing di negara pengimpor.

${ }^{19}$ Ramziati, Pengamanan Perdagangan Dalam Negeri (Safeguard) Dalam Teori dan Praktik, (Medan: Pustaka Bangsa Press, 2006), hlm. 57. 
Pengaturan masalah dumping yang berlaku dalam perdagangan internasional saat ini adalah peraturan yang tertuang dalam Agreement on Implementation of Article VI of GATT 1994 dan peraturan anti dumping dari masing-masing negara. Pengaturan anti dumping ini merupakan instrumen penting bagi pengamanan industri dalam negeri suatu negara anggota WTO dari praktik perdagangan tidak adil (unfair trade). Adapun pengaturan hukum mengenai anti dumping di Indonesia terdapat dalam UndangUndang Nomor 10 Tahun 1995 tentang Kepabeanan. Ketentuan mengenai anti dumping tercantum dalam Bab IV Pasal 18 sampai dengan Pasal 20, sedangkan Pasal 21 sampai dengan Pasal 23 mengatur mengenai bea masuk imbalan. Ketentuan ini yang menjadi dasar bagi pembuatan peraturan pelaksana tentang anti dumping di Indonesia. Adapun lembaga yang dibentuk pemerintah untuk melaksanakan instrumen anti dumping ini adalah KADI (Komite Anti Dumping Indonesia).

3. Standarisasi

Adanya kerja sama di bidang ekonomi antara negara-negara di dunia telah menciptakan sistem perdagangan dunia yang bebas (free trade). Sistem ini nantinya akan memperluas gerak arus transaksi barang dan/atau jasa melintasi batas-batas wilayah suatu negara sehingga pasar nasional nantinya akan bersifat terbuka terhadap barang dan/atau jasa impor. Untuk mendukung pasar nasional dalam menghadapi proses globalisasi perdagangan tersebut, dipandang perlu untuk menyiapkan perangkat hukum nasional di bidang standarisasi yang tidak saja mampu menjamin perlindungan terhadap masyarakat, khususnya di bidang keselamatan, keamanan, kesehatan, dan lingkungan hidup, tetapi juga meningkatkan pertumbuhan ekonomi nasional. Lebih lanjut, dalam perjanjian WTO sebagaimana telah diratifikasi oleh Indonesia dengan Undang-Undang Nomor 7 Tahun 1994, khususnya mengenai Agreement on Technical Barrier to Trade yang mengatur mengenai standarisasi, ditegaskan bahwa negara anggota diwajibkan untuk menyesuaikan peraturan perundang-undangan nasional di bidang standarisasi. Standarisasi dimaksudkan untuk meningkatkan perlindungan kepada konsumen, pelaku usaha, tenaga kerja, dan masyarakat lainnya, baik untuk keselamatan, keamanan, kesehatan, maupun pelestarian fungsi lingkungan hidup, serta untuk membantu kelancaran perdagangan dan mewujudkan persaingan usaha yang sehat dalam perdagangan. Untuk dapat meningkatkan efektifitas pengaturan di bidang standarisasi, diperlukan adanya peranan dan kerja sama yang sinergi antara konsumen, pelaku usaha, ilmuwan, dan instansi pemerintah. Standarisasi adalah proses merumuskan, menetapkan, menerapkan, dan merevisi standar yang dilaksanakan secara tertib dan bekerjasama dengan semua pihak. Adapun aturan yang mengatur mengenai standarisasi terdapat di dalam Peraturan 
Pemerintah Republik Indonesia Nomor 102 Tahun 2000 tentang Standarisasi Nasional. Standar Nasional Indonesia (SNI) adalah standar yang ditetapkan oleh Badan Standarisasi Nasional dan berlaku secara nasional. Penerapan Standar Nasional Indonesia adalah kegiatan menggunakan SNI oleh pelaku usaha. Pemberlakuan SNI adalah keputusan pimpinan instansi teknis yang berwenang untuk memberlakukan Standar Nasional Indonesia secara wajib terhadap barang dan/atau jasa. Sertifikasi adalah rangkaian kegiatan penerbitan sertifikat terhadap barang dan/atau jasa. Sertifikat adalah jaminan tertulis yang diberikan oleh lembaga/ laboratorium yang telah diakreditasi untuk menyatakan bahwa barang, jasa, proses, sistem atau personel telah memenuhi standar yang dipersyaratkan.

Berdasarkan Undang-Undang Nomor 5 Tahun 1984 tentang Perindustrian, industri didefinisikan sebagai kegiatan ekonomi yang mengolah bahan mentah, bahan baku, barang setengah jadi, dan/atau barang jadi menjadi barang dengan nilai yang lebih tinggi untuk penggunaannya, termasuk kegiatan rancang bangun dan perekayasaan industri. ${ }^{20}$ Berdasarkan definisi tersebut, maka industri dalam negeri yang dimaksud dalam hal ini, yaitu industri di Indonesia tampak jelas memiliki peran penting bagi perekonomian negara. Peran penting tersebut diantaranya untuk mendukung pertumbuhan ekonomi, penciptaan lapangan kerja, meningkatkan produktifitas, memperluas lapangan kerja, meningkatkan pemerataan dan pendapatan masyarakat, serta pengentasan kemiskinan.

Dengan adanya era globalisasi saat ini, khususnya dalam pemberlakuan MEA maka pembangunan industri negara-negara peserta menghadapi tantangan berupa persaingan yang semakin tajam. Dalam kondisi yang demikian, maka setiap negara peserta harus dapat menciptakan tingkat efisiensi dan produktifitas yang optimal serta mempunyai produk yang mempunyai daya saing yang tinggi. Dengan demikian, maka industri dalam negeri perlu untuk dilindungi agar industri dalam negeri tidak tergerus arus globalisasi.

Selanjutnya, Undang-Undang UMKM juga memberikan andil yang penting dalam perlindungan bagi industri dalam negeri. Selain itu, perlindungan industri dalam negeri juga tampak dalam aturan hukum berupa Peraturan Menteri Perdagangan Nomor 14/M-DAG/PER/ 3/2007 tentang Standarisasi Jasa Bidang Perdagangan dan Pengawasan Standar Nasional Indonesia (SNI) Wajib terhadap Barang dan Jasa yang Diperdagangkan. Pada Pasal 7 disebutkan bahwa terhadap barang produksi dalam negeri atau impor yang diperdagangkan di dalam negeri wajib dilakukan pengawasan SNI.

Ratifikasi yang dilakukan pemerintah atas Agreement Establishing the World Trade Organization, apabila dilihat dari segi hukum, merupakan suatu langkah yang tidak dapat dicegah dikarenakan sebagai negara berkembang dengan posisi yang lemah dalam pergaulan dagang internasional. Indonesia harus meletakkan tumpuan pada suatu forum multilateral, yakni WTO sebagai wujud suatu kekuasaan internasional di bidang perdagangan antarnegara yang diharapkan menegakkan rule

\footnotetext{
${ }^{20}$ Lihat Pasal 1 Angka 2 Undang-Undang Nomor 5 Tahun 1984 tentang Perindustrian.
} 
of law dalam masyarakat global. Adapun pihak yang paling membutuhkan perlindungan hukum adalah pihak yang posisinya paling lemah. Dalam lingkup internasional, efektifitas hukum tergantung dukungan negara-negara besar.

Sementara itu, negara-negara berkembang harus lebih gigih memperjuangkan posisi dan kepentingan-kepentingannya agar benar-benar menjamin keseimbangan dan keadilan antara pihak yang lemah dan pihak yang kuat. Keinginan ini tercermin dalam Pembukaan Undang-Undang Dasar 1945 yang menyatakan bahwa Pemerintah Indonesia ikut melaksanakan ketertiban dunia yang berdasarkan kemerdekaan, perdamaian abadi, dan keadilan sosial. Kepentingan setiap negara dalam proses negosiasi di tingkat bilateral maupun regional kian penting bagi Indonesia untuk menentukan sikap dan menempati posisi yang sejelas-jelasnya. Sebelumnya, perlu ditetapkan terlebih dahulu target jangka pendek dan jangka panjang yang hendak dicapai secara jelas sehingga biaya manfaatnya dapat terukur dan transparan. Hal yang paling penting mengaitkan strategi dan kebijakan pembangunan ekonomi domestik dengan langkahlangkah yang ditempuh pada tingkat internasional, dapat dilihat posisi pemerintah semakin lemah dalam menghadapi hambatan dalam mengupayakan peningkatan efisiensi dan daya saing nasional di perdagangan internasional. Dalam hal ini, pemerintah harus berupaya untuk menjalin kerja sama yang memungkinkan para produsen dalam negeri masuk ke dalam persaingan yang lebih ketat sehingga kesadaran akan pentingnya tekat untuk meningkatkan efisiensi usaha bisa berkembang lebih maju lagi. Dengan demikian, kesejahteraan konsumen dalam negeri dapat meningkat.

Indonesia merupakan salah satu negara anggota yang memiliki sumber daya alam yang melimpah diharapkan mampu bersaing secara bebas dengan negara-negara anggota ASEAN lainnya, baik dari segi kualitas maupun kuantitasnya. Hal ini karena kondisi ekonomi Indonesia masih lemah, demikian juga dengan tingkat pembangunan industrialisasi yang relatif cenderung masih rendah. Selain itu, Indonesia masih cenderung menerima produk-produk impor atau sebagai tempat pemasaran produkproduk dari negara-negara anggota ASEAN lainnya tanpa mampu bersaing dengan produk negara tersebut. Keadaan ini akan mengakibatkan industri-industri dalam negeri mengalami kemunduran karena tidak memiliki modal yang cukup untuk bersaing dengan industri dari negara anggota lainnya, baik dari segi jumlah produksi maupun pemasaran produk.

Sebagai suatu negara yang tingkat pertumbuhan industrinya masih dalam masa perkembangan, Indonesia masih menjalankan kebijakan proteksi yang cukup tinggi terhadap barang-barang impor untuk melindungi industri dalam negeri. Perbedaan kebijakan pengenaan bea cukai mencerminkan perbedaan daya saing komoditas-komoditas yang dihasilkan oleh masing-masing negara. Demikian pula dengan tingkat efisiensi produksi negara-negara anggota MEA yang lebih maju, umumnya sudah lebih tinggi dibandingkan dengan Indonesia, sehingga negara-negara tersebut mampu menerapkan bea masuk yang sangat rendah yang memberikan dampak positif bagi perdagangannya. Sementara itu, Indonesia belum berani menerapkan kebijakan tarif yang rendah. Hal ini tentu dilakukan guna melindungi dan mempertahankan produksi dalam negeri dengan mengenakan biaya masuk yang cukup tinggi, baik untuk menyaingi produksi impor maupun mengenakan kuota untuk barangbarang tertentu. 
Akses pasar dan modal seringkali tertutup bagi UMKM sehingga tidak heran jika demokrasi ekonomi hanya sekedar angin surga bagi UMKM. Keterbukaan pasar dengan menghapuskan perlakuan diskriminatif, favoritisme, dan pemberian konsensi pada pengusaha besar merupakan bagian dari kebijakan persaingan usaha yang terus ditumbuhkan sejalan dengan diberlakukannya Undang-Undang Nomor 5 Tahun 1999 tentang Larangan Praktik Monopoli dan Persaingan Usaha Tidak Sehat (selanjutnya disebut UU tentang Larangan Praktik Momopoli dan Persaingan Usaha Tidak Sehat). Kebijakan persaingan usaha yang ditujukan untuk mendorong terciptanya kesempatan berusaha yang sama antara pelaku usaha besar, menengah, dan kecil ini diharapkan akan mampu membuka akses pasar, modal, dan teknologi bagi UMKM. Salah satu tujuan pemberlakuan UU tentang Larangan Praktik Monopoli dan Persaingan Usaha Tidak Sehat adalah mewujudkan iklim usaha yang kondusif melalui pengaturan persaingan usaha yang sehat sehingga menjamin adanya kepastian kesempatan berusaha yang sama bagi pelaku usaha. ${ }^{21}$

\section{Pengaruh Pemberlakuan MEA Terhadap UMKM di Indonesia}

MEA merupakan kesepakatan antara negara-negara di Asia Tenggara untuk mewujudkan kawasan perdagangan bebas dengan menghilangkan atau mengurangi hambatan-hambatan perdagangan barang, baik tarif ataupun non tarif, peningkatan akses pasar jasa, peraturan dan ketentuan investasi, sekaligus peningkatan aspek kerja sama ekonomi untuk mendorong hubungan perekonomian para pihak dalam rangka meningkatkan kesejahteraan masyarakat ASEAN. Pada hakikatnya tujuan MEA dibentuk, yaitu untuk memperkuat dan meningkatkan kerja sama ekonomi, perdagangan, dan investasi antara negara-negara anggota, meliberalisasi secara progresif dan meningkatkan perdagangan barang dan jasa, serta menciptakan suatu sistem yang transparan untuk mempermudah investasi. Selain itu, juga menggali bidang-bidang kerja sama yang baru dan mengembangkan kebijaksanaan yang tepat dalam rangka kerja sama ekonomi antara negara-negara anggota. Apabila dilihat tujuan MEA berdampak positif, namun pada kenyataannya pemberlakuan MEA sangat berpengaruh terhadap pelaku usaha, khususnya kepada UMKM.

Pemberlakuan negara anggota ASEAN akan mengalami aliran bebas barang, jasa, investasi, dan tenaga kerja terdidik dari dan ke masing-masing negara. Dalam hal ini, yang perlu dilakukan oleh Indonesia sebagai bagian dari komunitas ASEAN berusaha guna mempersiapkan kualitas diri dan memanfaatkan peluang MEA, serta harus meningkatkan kapabilitas untuk dapat bersaing dengan negara anggota ASEAN lainnya sehingga ketakutan akan kalah saing di negeri sendiri akibat terimplementasinya MEA tidak terjadi. Terdapat 12 sektor prioritas yang akan diintegrasikan oleh pemerintah. Sektor tersebut terdiri dari tujuh sektor barang, yaitu industri agro, otomotif, elektronik, perikanan, industri berbasis karet, industri berbasis kayu, dan tekstil. Kemudian sisanya berasal dari lima sektor jasa, yaitu transportasi udara, kesehatan, pariwisata, logistik, dan teknologi informasi. Sektor-sektor tersebut pada era MEA akan terimplementasi

\footnotetext{
${ }^{21}$ Suyud Margono, Hukum Anti Monopoli, (Jakarta: Sinar Grafika, 2009), hlm. 34.
} 
dalam bentuk pembebasan arus barang, jasa, investasi, dan tenaga kerja. ${ }^{22}$

Berbagai kebijakan dan perlindungan hukum diperlukan agar pemberlakuan MEA tidak menggerus perekonomian Indonesia. Hal yang paling mendasar, yaitu dalam menekan harga produk lokal. Keberadaan UMKM berperan besar dalam penyediaan lapangan kerja dan penyediaan keperluan barang dan jasa dalam negeri. Keberadaan tersebut memberi petunjuk bahwa kebijakan pemberdayaan UMKM sangat strategis untuk mengurangi pengangguran dan meningkatkan pendapatan bagi sebagian besar rakyat, sekaligus pemerataan pembangunan.

UMKM merupakan motor penggerak perekonomian Indonesia yang menyentuh semua lini. Tidak dapat dipungkiri bahwa UMKM masih menghadapi sejumlah masalah yang hingga kini tidak mudah untuk diurai jalan solusinya, antara lain: ${ }^{23}$

1. Kualitas sumber daya manusia masih terbatas.

2. Keterbatasan penguasaan manajemen dan pengelolaan usaha yang tradisional.

3. Penggunaan teknologi.

4. Pemasaran terbatas.

5. Akses informasi rendah.

6. Keterbatasan akses permodalan/ kredit.

7. Legalitas usaha dan perlindungan usaha yang belum memadai.

Hampir seluruh UMKM merupakan pelaku yang masih sangat membutuhkan sentuhan langsung dari pemerintah karena kondisi mereka yang tidak cukup mampu mengakses sumber pembiayaan untuk mulai melakukan usaha bagi sektor mikro serta sumber daya untuk memperbesar kapasitas usaha mereka bagi sektor kecil dan menengah. Selain itu, masih terdapat cukup banyak kendala lain, yaitu dari pengembangan sumber daya manusia, pemasaran, dan perbaikan sistem produksi.

Dampak dari pemberlakuan MEA adalah ketergantungan ekonomi Indonesia akan semakin tinggi. Dampak lainnya, yaitu mengakibatkan melemahnya daya serap tenaga kerja, yang berujung meningkatnya pengangguran dan melambatnya pertumbuhan investasi. Kesepakatan pemberlakuan MEA tersebut justru membuat industri lokal gelisah, khususnya bagi pelaku UMKM. Produk-produk dalam negeri masih memiliki biaya produksi yang cukup tinggi sehingga harga pasaranpun masih sulit ditekan. Keadaan ini dikhawatirkan akan memicu pemutusan hubungan kerja dikarenakan ditutupnya perusahaan dalam negeri akibat kalah bersaing. Biaya produksi di Indonesia tergolong tinggi sehingga harga pasarpun lebih tinggi.

Kesiapan menghadapi MEA juga harus dipahami bukan hanya oleh pemerintah selaku perangkat negara melainkan oleh masyarakat secara keseluruhan, karena dengan pemberlakuan kelak masyarakat Indonesia akan merasakan atau terkena dampak sehingga dibutuhkan sosialisasi dan edukasi terkait ASEAN Economic Community kepada masyarakat dan dibutuhkan kebijakan menyikapi hal ini, karena bukan rahasia bahwa negaranegara anggota ASEAN lainnya juga turut mempersiapkan diri menghadapi AEC. ${ }^{24}$

\footnotetext{
22 Jeffry H. Sinaulan, Peran Penting Etika Bisnis Bagi Perusahaan-perusahaan Indonesia, Jurnal Analisis Ekonomi Utama, Volume X, Nomor 2, Tahun 2016, hlm. 23.

${ }^{23} \mathrm{lbid}, \mathrm{hlm} .29$.

${ }^{24}$ Masnur Tiurmaida Malau, Aspek Hukum Peraturan dan Kebijakan Pemerintah Indonesia Menghadapi Liberalisasi Ekonomi Regional Masyarakat Ekonomi ASEAN 2015, Jurnal Ilmu Hukum, Volume 3, Nomor 2, Tahun 2014, hlm.16.
} 
Berkaitan dengan pengaruh yang ditimbulkan atas pemberlakuan MEA, pemerintah wajib menetapkan bidang usaha yang dicadangkan untuk UMKM agar mampu dan sejajar dengan pelaku ekonomi lainnya. Dalam hal ini, pemerintah juga melakukan pembinaan dan pengembangan UMKM melalui program kemitraan, peningkatan daya saing, pemberian dorongan inovasi, dan perluasan pasar, serta penyebaran informasi yang seluas-luasnya. Seiring dengan kebijaksanaan pemerintah dalam memandu laju perekonomian melalui mekanisme ekonomi pasar, kegiatan usaha pada setiap lapisan masyarakat serta menyangkut semua kegiatan usaha yang dilakukan oleh para pelaksana ekonomi perlu dilandasi oleh ketentuan hukum yang mendorong bekerjanya mekanisme ekonomi pasar yang baik dan wajar. Pesatnya perkembangan dunia usaha adakalanya tidak diimbangi dengan penciptaan rambu-rambu pengawas. Dunia usaha yang berkembang terlalu pesat sehingga meninggalkan ramburambu yang ada jelas tidak akan menguntungkan pada akhirnya. Apabila hukum tidak ingin dikatakan tertinggal dari perkembangan bisnis dan dunia usaha maka hukum dituntut untuk merespon segala seluk-beluk kehidupan dunia usaha yang melingkupinya sebagai suatu fenomena atau kenyataan sosial.

Apabila dipahami, dalam pasar bebas harus dicegah penguasaan pasar oleh satu, dua, atau beberapa pelaku usaha saja (monopoli dan oligopoli) karena dalam pasar yang hanya dikuasai oleh sejumlah pelaku usaha maka terbuka peluang untuk menghindari dan mematikan bekerjanya mekanisme pasar (marketmechanism) sehingga harga-harga ditetapkan secara sepihak dan merugikan konsumen. ${ }^{25}$ Pengaturan hukum untuk menjamin terselenggaranya pasar bebas secara adil mutlak diperlukan. Akses pasar dan modal seringkali tertutup bagi UMKM sehingga tidak heran jika demokrasi ekonomi hanya sekedar angin surga bagi UMKM. Keterbukaan pasar dengan menghapuskan perlakuan diskriminatif dan pemberian konsensi pada pengusaha besar merupakan bagian dari kebijakan persaingan usaha yang terus ditumbuhkan.

Pada kenyataannya, jumlah UMKM sangat mendominasi struktur ekonomi di Indonesia, yakni sekitar 99,9\%. Di samping itu, jumlah usaha mikro yang sangat kecil mencapai $98,8 \%$. Usaha skala mikro ini umumnya merupakan usaha informal yang dikelola oleh wirausahawan informal yang menjadi penyangga penyerapan tenaga kerja. Pemerintah pusat dan pemerintah daerah harus lebih serius mengatasi masalah sektor informal karena sektor ini harus dijadikan basis wirausahawan mandiri informal untuk ditransformasikan menjadi formal. Dalam hal ini, birokrasi harus ramah terhadap usaha mikro dan kecil ini sehingga lebih mudah untuk didorong naik tingkat. Selain itu, pemerintah perlu melakukan konsolidasi kelembagaan, investasi teknologi terapan tepat guna, dan mendorong kewirausahaan UMKM melalui pendidikan. ${ }^{26}$

Diplomasi ekonomi dan perdagangan Indonesia dinilai masih lemah. Seringkali negosiasi dengan pihak mitra asing tidak dilakukan dengan cermat dan sering diabaikan dengan menyerahkan pada pelaku negosiasi eselon bawah. Dengan pola strategi diplomasi

${ }^{25} \mathrm{Ibid}$, hlm. 20.

${ }^{26} \mathrm{Ibid}$. 
dagang seperti ini maka Indonesia selalu kalah dan menjadi korban sehingga beban kerugian yang besar ditanggung oleh dunia usaha. Kamar Dagang dan Industri (Kadin) Indonesia menilai pengawasan terhadap pelaksanaan SNI secara wajib kurang berjalan optimal. Penyebabnya jumlah dan kemampuan teknis aparat masih minim. Masalah klasik yang muncul dalam menangani produk nonstandar, baik impor maupun produksi dalam negeri, terletak pada koordinasi antarinstansi terkait. Padahal, implementasi sejumlah SNI wajib sejak beberapa tahun terakhir belum mampu membendung serbuan produk nonstandar karena masih ada pemalsuan merek, label, dan produk. Selama ini belum maksimalnya upaya dari pemerintah untuk mensosialisasikan kepada masyarakat sebagai konsumen tentang pentingnya memilih produk berlabel SNI. Oleh karena itu, pemerintah sudah saatnya menggencarkan sosialisasi kepada masyarakat agar menjadi konsumen yang selalu mengkonsumsi produk ber-SNI sebagai acuan untuk mendapatkan produk yang memenuhi standar kualitas.

Indonesia diduga memiliki standar yang terlampau rendah dalam menyeleksi barang impor. Perang dagang antar negara dengan mengedepankan proteksionisme akan semakin banyak terjadi seiring dengan lemahnya perdagangan dunia akibat perlambatan ekonomi global. Pemerintah diharapkan memperkuat negosiasi untuk menghadapinya dan tidak bersikap pasif. Lemahnya kemampuan diplomasi perdagangan Indonesia. Bahkan, pemerintah pasif menghadapi kecurangan dagang yang dihadapi industri nasional. Pemerintah seharusnya proaktif terhadap masalah-masalah perdagangan. Tetapi, bukan berarti Indonesia tidak bisa mengambil langkah melindungi produk dalam negeri di pasar domestik. Apabila benar-benar ingin, pemerintah dapat menerapkan proteksi secara halus dengan meningkatkan standar keamanan dan kesehatan terhadap produk-produk impor yang masuk ke Indonesia.

Peluang-peluang ekspor usaha kecil dan menengah daerah memiliki potensi menjadi ujung tombak dalam pendapatan daerah. Di tingkat daerah, potensi demikian beragam mulai dari perkembangan pariwisata, pertanian, hingga industri. Hanya saja, potensi ekspor yang demikian besar belum didukung dengan adanya pembiayaan yang memadai. Masa depan Indonesia ada di daerah dengan potensi produkproduk ekspornya. Daerah harus bisa dipacu melakukan perdagangan tidak hanya untuk lokal saja, tetapi perdagangan internasional. Agar produknya berdaya saing, pelaku usaha kecil dan menengah yang berorientasi ekspor perlu melakukan inovasi. Namun, inovasi ini membutuhkan pembiayaan. Saat ini, produkproduk lembaga keuangan, termasuk bank komersial, belum seluruhnya dapat dipergunakan secara optimal dan tidak sepenuhnya bisa diharapkan untuk menyelesaikan persoalan ini. Diharapkan Kadin, selain melaksanakan pembekalan secara berkala tentang prosedur ekspor, melakukan pelatihan dan promosi bagi pelaku usaha daerah dalam bentuk klinik bisnis, juga memberikan bantuan permodalan maupun penjaminan proyek melalui lembaga pembiayaan.

Peran pelaku usaha daerah untuk bisa melakukan ekspor memiliki arti penting tersendiri karena dengan melakukan perdagangan luar negeri bisa meningkatkan pendapatan, membuka kesempatan kerja, mengembangkan industri baru, juga meningkatkan penghasilan devisa. Arah strategi perdagangan internasional ke depan akan diprioritaskan kepada empat hal, yakni intensifikasi promosi dan diplomasi 
perdagangan internasional melalui pendekatan komoditi dan negara tujuan ekspor. Pemerintah daerah jangan hanya mendukung perusahaan besar pengekspor saja, tetapi perlu banyak mengarah untuk membantu pelaku usaha kecil dan menengah yang berorientasi ekspor. Pemerintah harus terus mendorong agar ekspor tidak hanya bergantung pada produk alam, seperti sektor migas dan pertambangan yang akan habis dan tidak akan diperbarui, tetapi meningkatkan ekspor yang berasal dari produk olahan yang mempunyai nilai tambah, seperti produk-produk dari sektor agribisnis, industri kreatif, dan lain-lain. Dampak dari perdagangan bebas terus berpengaruh di dalam negeri, ditambah lagi dengan kondisi krisis di Eropa yang terus berkelanjutan, mengakibatkan Indonesia menjadi target pasar dunia karena terjadinya penurunan permintaan ke negara-negara yang mengalami krisis. Akhirnya, Ionjakan imporpun tidak dapat dibendung. ${ }^{27}$

\section{Kesimpulan}

1. Perlindungan hukum terhadap kelangsungan UMKM atas pemberlakuan MEA diberikan dalam bentuk peraturan perundang-undangan, yaitu UndangUndang Nomor 20 Tahun 2008 tentang Usaha Mikro, Kecil, dan Menengah, Peraturan Menteri Perindustrian Nomor $37 /$ M-IND/PER/6/2006 tentang Pengembangan Jasa Konsultasi bagi Industri Kecil dan Menengah, dan Peraturan Menteri Perdagangan Nomor 14/M-DAG/PER/3/ 2007 tentang Standarisasi.

2. Terdapat pengaruh positif dan negatif pemberlakuan MEA terhadap UMKM di Indonesia. Pengaruh positifnya UMKM di
Indonesia memiliki kesempatan untuk mengembangkan usahanya di negaranegara ASEAN lainnya, sedangkan pengaruh negatifnya UMKM di Indonesia sebagian besar belum siap untuk bersaing dengan UMKM dari negara-negara ASEAN lainnya karena faktor permodalan, teknologi, dan pemasaran.

\section{Saran}

1. Berkaitan dengan perlindungan hukum terhadap kelangsungan UMKM atas pemberlakuan MEA maka sebaiknya memperbaiki dan regulasi dan kebijakan, baik sektoral maupun daerah, yang dapat menghambat pengembangan UMKM.

2. Berkaitan dengan pengaruh pemberlakuan MEA terhadap UMKM di Indonesia maka sebaiknya pemerintah membantu akses permodalan, teknologi, dan strategi pemasaran bagi UMKM agar mampu bersaing menghadapi tantangan MEA serta menciptakann iklim usaha yang kondusif bagi UMKM.

\section{Referensi}

Abdul Kadir Muhammad. 2004. Hukum dan Penelitian Hukum. Bandung: Citra Aditya Bakti.

Atep Abdurofiq. Menakar Pengaruh Masyarakat Ekonomi Asean 2015 Terhadap Pembangunan Indonesia. Jurnal Sosial dan Budaya Syar'i. Volume 1. Nomor 2. Tahun 2014.

Boediono. 1981. Ekonomi Internasional. Yogyakarta: BPFE.

Hendera Halwani. 2002. Ekonomi Internasional dan Globalisasi Ekonomi. Jakarta: Ghalia Indonesia.

\footnotetext{
${ }^{27} \mathrm{http}: / /$ www.Kadin-Indonesia.or.id/Kadin-Pusat/Daerah, diakses terakhir tanggal 30 Oktober 2017.
} 
Jeffry H. Sinaulan. Peran Penting Etika Bisnis bagi Perusahaan-perusahaan Indonesia. Jurnal Analisis Ekonomi Utama. Volume X. Nomor 2. Tahun 2016.

Karen Lebacqz. 1986. Teori-teori Keadilan. Bandung: Nusa Media.

Masnur Tiurmaida Malau. Aspek Hukum Peraturan dan Kebijakan Pemerintah Indonesia Menghadapi Liberalisasi Ekonomi Regional Masyarakat Ekonomi ASEAN 2015. Jurnal Ilmu Hukum. Volume 3. Nomor 2. Tahun 2014.

Mochtar Kusumaatmadja dan Etty R. Agoes. 2003. Pengantar Hukum Internasional. Bandung: PT Alumni.

Mohd. Burhan Tsani. 1990. Hukum dan Hubungan Internasional. Yogyakarta: Liberty.

Ramziati. 2006. Pengamanan Perdagangan Dalam Negeri (Safeguard) Dalam Teori dan Praktik. Medan: Pustaka Bangsa Press.

Rifai Afin, Herry Yulistio, dan Nur Alfillai Oktariani. Perdagangan Internasional, Investasi
Asing, dan Efisiensi Perekonomian Negara-negara ASEAN. Jurnal Ekonomi dan Bisnis. Volume 8. Nomor 5. Tahun 2008.

Soejono Soekanto dan Sri Mamudji. 2009. Penelitian Hukum Normatif; Suatu Tinjauan Singkat. Jakarta: PT Raja Grafindo Persada.

Suyud Margono. 2009. Hukum Anti Monopoli. Jakarta: Sinar Grafika.

Syahmin AK. 2006. Hukum Dagang Internasional dalam Kerangka Studi Analitis. Jakarta: PT Raja Grafindo Persada.

Teguh Sulistia. Perlindungan Hukum dan Pemberdayan Pengusaha Kecil Dalam Ekonomi Pasar Bebas. Jurnal Hukum Bisnis. Volume 27. Nomor 1. Tahun 2008.

Yunita R. Panjaitan. Perlindungan Hukum Terhadap Usaha Mikro. Kecil dan Menengah Dalam Pasar Bebas AseanChina Free Trade Area. Jurnal Hukum Ekonomi. Volume 1. Nomor 2. Tahun 2013. 